\title{
HOW INVESTORS REACT TO POLITICAL RISK
}

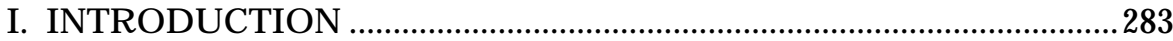

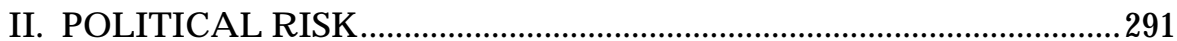

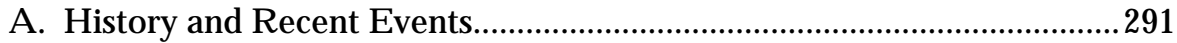

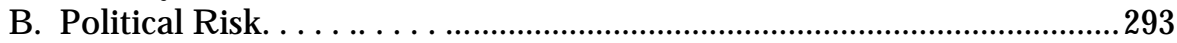

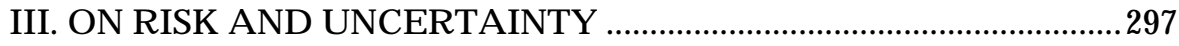

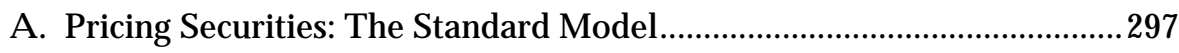

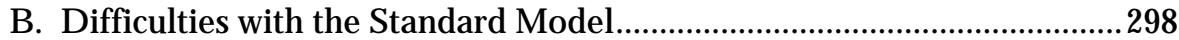

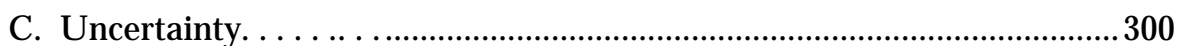

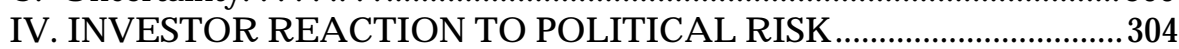

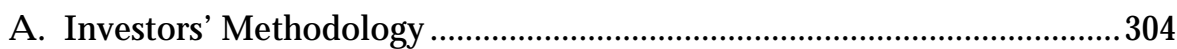

B. The Cycle. . . . . . . . . . . . .

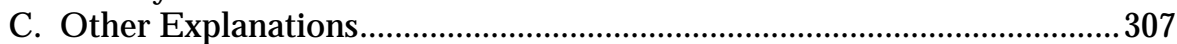

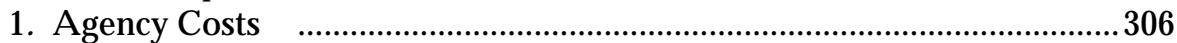

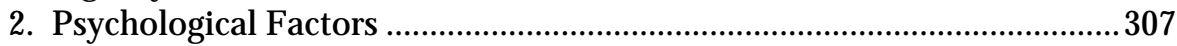

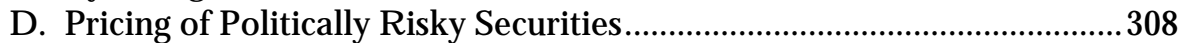

E. Implications for M odigliani and M iller's Capital Structure

I rrelevance Theorem...................................................309

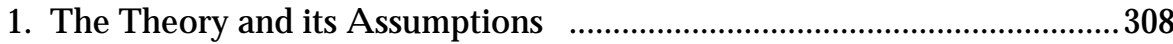

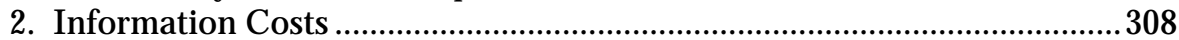

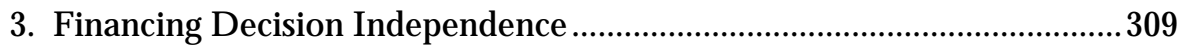

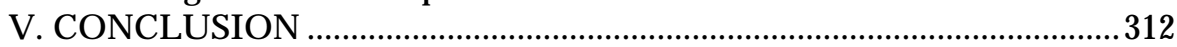

$$
\begin{aligned}
& \text { CLAIREA. HILL }{ }^{*} \\
& \text { Investors know there was a civil war here [in Moldova] and it puts } \\
& \text { people off. }{ }^{1}
\end{aligned}
$$

\section{INTRODUCTION}

In the summer of 1997, E ast A sian financial markets caught the "A sian flu." The crisis began when Thailand's currency, the baht, weakened in response to international pressure; the crisis soon

*A ssistant Professor of $L$ aw, G eorge M ason U niversity School of $L$ aw. I wish to acknowledge helpful conversations with B rian Bix, B ernie Black, E ric B othwell, Tyler Cowen, L eo K atz and Charles Trzcinka. I also wish to acknowledge helpful research assistance of $\mathrm{K}$ ate Costenbader, G eorge M ason U niversity School of L aw Class of 1999.

1. A n Investment Guide to M oldova, Trouble With Neighbors, EUROM ONEY, Sept. 1997, at Supp. 2-3, available in LEXIS, B usfin Library, A bi File. 
spread throughout the region. ${ }^{2} \quad$ The flu "worsened" into "pneumonia," ${ }^{3}$ and another crisis erupted in Russia. ${ }^{4}$ M arkets all over the world have been affected; emerging markets have been particularly hard hit.

Since the A sian crisis began, foreign investors have been skittish of all emerging markets investment. ${ }^{5} \mathrm{M}$ any foreign investors have largely refrained from investing in the region. They have invested only in securities with elaborate quality and safety-enhancing mechanisms, or demanded a very high "lemons" discount to reflect their worst case estimate. ${ }^{6}$ Before the A sian crisis, investors ${ }^{7}$ had become

2. See, e.g., Lawrence Summers, Go with the Flow: The Rush to Support Capital-A ccount Controls in the Wake of the A sian Crisis is M isconceived, FIN.. TIMES (L OND ON), M ar. 11, 1998, at 14. See also Claire A . H ill, L atin A merican Securitization: The Case of the D isappearing Political Risk, 38 VA. J. INTL. L. 293, n. 18 and accompanying text (1998) [hereinafter Latin A merican Securitization].

3. Summers, supra note 2. See also R uss Wiles, L oaded for B ear; D on't Plan on Q uick Rebound from A sia's Market Fiasco, A RIZONA REPUBLIC, J an. 4, 1998, at D 1, available in LEXIS, News Library, A zrep File.

4. See, e.g., Paul B lustein, Financial Crises Could Stall Capitalism's G lobal M arch, WA SH. Post, Sept. 4, 1998 at A 1 [hereinafter Financial Crises].

5. For a time, however, it seemed that investor skittishness was lessening. See $L$ atin A merica: Fragile Finance, E conomist, M ar. 21, 1998, at 87. See also South K orea Prospers on Debut, CORP. MONEY, A pr. 15, 1998, at 8; J erry Edgerton, Rebounding E merging M arkets B ond Funds O ffer L ofty $Y$ ields-If $Y$ ou Can $\mathrm{H}$ andle the R isks, M ONEY, M ay 1998, at 42.

$\mathrm{N}$ ot too long ago, only investors with an $\mathrm{E}$ vel-K nievel-like tolerance for risk would have considered emerging markets bonds. A fter all, at last fall's A sian economic crisis reverberated through developing nations from the Pacific R im to L atin A merica to E astern E urope, emerging markets bond prices plummeted by $15 \%$. Now, in the wake of the International M onetary Fund's bailout of K orea and other countries, these bonds have been making a comeback.

B ut investors' return to emerging markets investing was short-lived; by the end of A pril, difficulties in A sia were again receiving investors' attention and commanding prudence, as were, by the middle of $M$ ay, the increasing signs of crisis in R ussia. See, e.g., Paul Blustein, A sia J itters $\mathrm{H}$ it $\mathrm{O}$ ther Markets; Russian, Latin Stock Indexes Drop, WASH. PoST, May 19, 1998 at C1 [hereinafter A sia J itters].

6. My Article explores foreign investors' reactions to politically risky securities (securities issued by or on behalf of emerging markets firms or countries), and, principally, reactions of foreign investors seeking quality and liquidity, foreign capital market investors. (I use the term "securities" broadly to include any financial instrument an investor might buy, however structured.) Capital market investors include many of the world's largest investors. Some of these investors are institutions subject to quality-favoring regulatory regimes, such as insurance companies and pension funds. See Claire A. H ill, Securitization: A L ow-C ost Sweetener for L emons, 74 W A SH. U. L.Q. 1061, 1070-71 nn.38-44 (1996) (discussing the regulatory regimes applicable to many institutional investors) [hereinafter $L$ emons]. Thus, my references to "investors" are primarily to foreign capital market investors. O ther foreign investors, such as those who specialize in highly speculative investments, offer less desirable investment terms; there is less of an analytic puzzle for investment activities in which the investor includes a considerable margin for error. Thus, my analysis takes account of such investors mainly in characterizing emerging markets investment immediately after a dramatic and unfavorable event has occured, until the foreign capital markets investors return. I consider only briefly domestic in- 
sanguine about political risk; the discount for exposure to political risk had shrunk to low levels. ${ }^{8}$

The pattern is familiar. The 1994 peso crisis $^{9}$ and the Latin A merican defaults of the mid-1980s ${ }^{10}$ were preceded by investing terms ${ }^{11}$ that hindsight suggests were too lax. ${ }^{12}$ For a time afterwards, investors shied away from emerging markets. ${ }^{13}$ Eventually, they re-

vestors in a firm's (politically risky) home country. The situation for domestic investors in a country subject to appreciable political risk is analytically distinct: since such investors cannot really avoid exposure to the risk in any event, the incremental effect of purchasing a particular firm's politically risky securities is difficult to untangle.

7. Finance theory characterizes some subset of investors as "arbitrageurs." A rbitrageurs stand ready to identify and correct pricing "mistakes," including, in some theories, those reflecting mistaken assessments of risks. A rbitrageurs have access to infinite resources to support their activities. O ther investors, by contrast, may sometimes make incorrect assessments. For a discussion of the role of arbitrageurs in finance theory, see generally R onald J. G ilson \& R einier H. K raakman, The M echanisms of M arket E fficiency, 70 V A. L. REV. 549 (1984). In my account, I generally do not distinguish between arbitrageurs and other investors; rather, all investors are making a "correct" assessment given information and other limitations. However, in Section IV.C, infra, I consider whether some investors may be making pricing mistakes. In Section IV .D , infra, I discuss arbitrageurs' role in correcting those mistakes.

8. See H ill, L atin A merican Securitization, supra note 2, at 311 . See also L atin A merica: Fragile Finance, supra note 5 , at 87.

For much of last year [1997], Latin governments and companies could sell bonds abroad at extraordinarily low rates. When the market dried up in 0 ctober, spreads between Latin A merican bonds and A merican Treasury bonds soared. They have slowly narrowed since then, and some new countries, such as A rgentina and M exico, have tested the market with new issues. But these have been at shorter terms ... and higher rates than they obtained last year.

Id. at 87. See also Paul Blustein, 'Spread' the Bad Word in Emerging Markets' Downfall, W A SH. POST, D ec. 4, 1997, at E 1 [hereinafter Spread].

In A pril 1997, shortly before the A sian crisis erupted full force, [big institutional investors] were so eager to participate in the emerging market boom that, according to the [Institute of International Finance], they were accepting average yields just 1.17 percentage points above Treasuries on bonds in 14 major emerging markets, down from 3.27 percentage points in O ctober 1995.

Id.

9. See H ill, L atin A merican Securitization, supra note 2, at 310.

10. See id. at 304-05.

11. For analytic ease, I gloss over risks of these securities other than political risks, sometimes referring to such securities as "politically risky securities;" I also omit mention of the securities' rewards, speaking as though they only had risk. I also largely gloss over specific attributes of a security, such as whether it is structured as debt or equity; however, my focus is principally on debt instruments, since foreign capital markets investors have a longer history of investing in such instruments. Moreover, I also gloss over the different types of structures, some of which are quite elaborate indeed (and others of which are quite simple), except to the extent I address systematic differences in the investors who invest in particular types of transactions. Finally, while I focus mostly on passive investors and investments, I include among my sources materials relating to more active investments, such as running a business; active and passive investors share many of the same concerns about political risk.

12. See Hill, L atin A merican Securitization, supra note 2, at 304-05.

13. See id. at 306. 
turned in droves, ${ }^{14}$ driving down the discount for political risk exposure $^{15}$ until the A sian crisis jolted it back up. Future flows securitization, a financing technique used by some firms in emerging markets countries, illustrates the strength of investor reaction to political risk. The technique minimizes investors' exposure to political risk, but only by means of elaborate and costly structuring. ${ }^{16}$

B oth conventional wisdom and ample anecdotal evidence suggest that investors have difficulty with political risk assessment-that investors often alternate between assessments that, in hindsight, were either much too high or much too low. ${ }^{17}$ In a sense, all assessments that, in retrospect, prove wrong, were either too high or too lowwhat else could they be? What makes my claim something other than trivially tautological is the pattern I hypothesize, of alternating optimism and skittishness. ${ }^{18}$ A s one market participant noted, "[w]e get lulled into a period where [political risk] seems as if it's not as important as it was in the past. But there's always a new nasty shock that appears." $^{19}$ In this A rticle, I take as a starting point that investor re-

14. Indeed, an interesting, although not surprising, feature of emerging markets investment is that liquidity is profoundly affected by the course of events. When the investment climate is favorable, emerging markets specialists and high-yield specialists are joined by more safety-conscious institutional investors. When sentiment turns skittish, the market thins, and the safety-conscious institutional investors, who represent large amounts of funds, turn elsewhere. Investors know that they do not know very much and reasonably believe that they may soon know much more. Therefore, they wait. See Section IV.B infra. See also Hill, L atin A merican Securitization, supra note 2, at 306 (discussing the history of safety-and-quality conscious investors' return to $L$ atin A merican markets).

15. Id. at $309 \mathrm{nn} .69-71$.

16. I discuss future flows securitization as used by emerging markets firms in $\mathrm{H}$ ill, $\mathrm{L}$ atin A merican Securitization, supra note 2.

17. See David Goldman, Fool Me Twice, Shame on Me, Forbes, May 19, 1997, at 279; Paul B lustein, Investors Reconsider Big E merging M arkets B ets, W A SH. POST, J uly 20, 1997, at $\mathrm{H} 1$ [hereinafter Investors Reconsider]. My evidence also includes many conversations with practitioners in the field.

18. For ease of analysis, and consistent with intuition, I somewhat stylize the pattern of investor sentiment about political risk, and overstate the qualitative differences between such sentiment and investor sentiment about other risks. Certainly, particular securities and industries and investment strategies sometimes enjoy alternating investor confidence (favor) and skittishness (disfavor). I cast the distinction between political risk and other, more "standard" risks investors face as qualitative to capture two intuitions. First, sentiment about political risk seems more intractably cyclical. Second, and more importantly, as I argue in this article, the uncertainties surrounding political risk seem (and are) more difficult to address. In contrast, when an investor buys a broad-based domestic mutual fund, risks and uncertainties associated with particular securities need no longer concern her.

19. H arvey Shapiro, Know Y our L ocal Candidates, INFRA STRUCTURE FIN., O ct. 1996, at 54, available in LEXIS, News Library, Inffin File. The investors described in the following quote are presumably among those Shapiro's source is thinking of:

A ssets that last year you could not move for love or money are this year's vogue, said 
action fits the pattern I describe ${ }^{20}$ and attempt to account for the pattern. I explore attributes of political risk that might make it particularly difficult to assess, and how investors might react in the face of these assessment difficulties.

No one can perfectly predict the future. In many situations, however, we can make good predictions, because we can extrapolate from sufficiently similar, or homogeneous, past events. We can predict possible outcomes and their payoffs, as well as their associated probabilities, with an appreciable degree of confidence and precision. B y contrast, in other situations our predictions require extrapolation from dissimilar (heterogeneous) events, ${ }^{21}$ these predictions will not be nearly as good. Frank H. K night, in his classic book R isk, U ncertainty and Profit, $^{22}$ distinguished these two situations; he labeled the first "risk" and the second "uncertainty." ${ }^{23} \mathrm{R}$ isk can be adequately quantified; the more homogeneous the events, the more we know about the distribution of possible outcomes. By contrast, quantification of

H oward Snell, director of emerging markets at Swiss Bank Corp. in London, citing debt of Sudan and Nicaragua as well as I vory Coast. He said such debt was popular whether the countries have any known means or plans to pay off their debts or not. In the heady if not always logical world of emerging markets investing, last year's untouchables have become this year's under-valued icons. In 1993 an estimated \$1 million of emerging market debt changed hands in a market centered on London and $\mathrm{N}$ ew $\mathrm{Y}$ ork. This year, many people expect that figure to double.

See also Erik Ipsen, Mideast and Africa Now Lure Adventurous Investors, INT'L HERALD TRIB., J an. 19, 1994, at A 1, available in LEXIS, N ews Library, I ht File. Of course, to the extent investors are buying debt of countries with no known repayment means or plans at anything other than extremely low prices, I would not argue that their valuations are "the best they can do;" rather, I would agree with the author of the quote, who clearly believes these investors are paying too much.

20. M ore precisely, I assume that the lawyers and bankers I have spoken to, and the commentators writing on the matter, have gauged investor sentiment accurately. But see note 27 , infra.

21. I argue in Section III.C, infra, that events are not inherently homogeneous or heterogeneous, but that for many purposes, we can speak as though they were.

22. FRANK H. KNIGHT, RISK, UNCERTAINTY AND PROFIT (1921).

23. What $\mathrm{K}$ night really meant by uncertainty, and the role the concept plays in his theories, has been discussed and debated by scholars. See, e.g., James M. Buchanan \& A lberto Di Pierro, Cognition, Choice, and Entrepreneurship, 46 S. E con. J. 693 (1980); Thomas I. Palley, Uncertainty, Expectations and the Future: If We D on't K now the A nswers, What are the Questions, 16 J. POST-KEYNESIAN E CON. 3 (1993), available in LEXIS, Busfin Library, A sapii File. $M y$ account follows K night's original definition of uncertainty. See Section III.C, infra. A nother term sometimes used by scholars, "ambiguity," has a similar meaning. See, e.g., Hillel J. Einhorn \& Robin M. Hogarth, Decision Making Under A mbiguity, in R A TIONAL CHOICE 41 (Robin M. Hogarth \& M ervin W. Reder eds., 1987). Sometimes, both "uncertainty" and "ambiguity" are used to refer to an individual's state of mind rather than a state of the world. In this usage, an individual could be "uncertain" about a matter engendering certainty in many, or even most, other individuals. In my use of the term "uncertainty," individuals generally are uncertain. 
"uncertainty" is far more difficult; indeed, the more heterogeneous the events, the less we know about the distribution of possible outcomes. ${ }^{24}$

Political risk is quite heterogeneous. E ach event differs markedly. Moreover, as the world changes, the profile of political risk changes. Several decades ago, the most feared political risks were nationalization or expropriation, such as occurred in Chile with A naconda Copper. N ow, currency and exchange controls, as well as general instability compounded by increasing globalization of markets, are more prominent in investors' minds. ${ }^{25}$ Of course, investors are continually revising their assessments of all risk and uncertainty with new information. Moreover, few assessments they make involve events which fit comfortably within one homogeneous class; rather, there is always some degree of heterogeneity. But few events belong to classes as heterogeneous as political risk.

Indeed, political risk is not an obvious "class" in the way that, for instance, "people" or particular colors are. When we designate someone as being a person or something as being red, we are typically not changing the definition of what it means to be a person or red. ${ }^{26}$ But a new event within the class of political risk can revise the definition of political risk itself. By contrast, for events within more homogeneous classes, new information should prompt far less revision: even a dramatic event within a homogeneous class can readily be incorporated into the previously established probability distribution. O ne business's failure in the normal course often will not affect the overall rate of business failures, or the causes thereof. But an event involving political risk, such as the recent A sian or R ussian crisis, can cause a far larger revision. The prior probability distribution was not known with great precision or confidence; the A sian and R ussian crises may very well indicate a dramatic change in the investment climate in emerging market countries, at least for the near to moderate term.

Thus, when assessing political risk during or shortly after a crisis,

24. See KNIGHT, supra note 22 , at 233. O ne article considering the effect of uncertainty (here, called "ambiguity") in finance is J ie $\mathrm{H}$ ue, Information A mbiguity: Recognizing its Role in Financial M arkets, FED. RESERVE BANK OF A TLA NTA, J uly/A ug. 1994, at 11-21.

25. See infra notes $52-63$ and accompanying text.

26. A ctually, philosophers are notorious for trying to stretch the boundaries of classes everyone thinks are well-understood. One famous example involves bachelors who somehow manage to be married. Fred Schauer justly denigrates these types of examples as "arguments from weird cases." Frederick Schauer, E asy Cases, 58 S. CAL. L. REV. 399, 419-423 (1985) (". . the argument from weird cases says almost nothing at all." Id. at 423.) 
investors use the best information they have-information as to the recent crisis. They stay out of the market or demand very high rates. If time passes without incident, investors eventually obtain sufficient positive information to reverse the negative impact of a crisis: stability continues, investors get their promised returns, and perhaps, the country takes steps to clarify and expand enforcement of firminvestor bargains. But there is a lag during which the lemons discount remains high. E merging market securities then become attractive, more investors enter the market, ${ }^{27}$ and the discount shrinks. Sooner or later, another crisis occurs, and the cycle begins again.

On this account cycling of investor sentiment does not lead to incorrect pricing. ${ }^{28} \mathrm{R}$ ather, it represents a rational investor's best guess. When the investor appraises as plausible an event with very bad consequences, he refrains from investing (or demands a very high discount); when he does not, he may invest, taking only a small lemons discount. This response is the best investors and the market can do.

T wo other dynamics might contribute to cycling: investor irrationality, ${ }^{29}$ and institutional and regulatory incentives for investors to "stay with the pack." Both dynamics could lead investors to pay

27. Here, as in this A rticle more generally, I gloss over differences among different emerging markets firms, industries, countries and regions, treating emerging markets investment as monolithic. The differences are significant, but not in ways that affect my analysis. O ne caveat, though: one difference that is significant is the "panic-selling" of emerging markets investments in countries with sound 'fundamentals' (including, for this purpose, very little political risk.) $\mathrm{M}$ y focus in this $\mathrm{A}$ rticle is on investor reaction to emerging markets investment in countries with appreciable political risk. Where the panic-selling reflects "contagion," not of bad economic developments, but of 'pure' sentiment, I would not make the claim that investors were being rational. R ather, I would tell a story akin to Keynes' famous 'beauty contest' story, in which investors are trying to outguess each other rather than compute (or guess) fundamentals. See J OHN M. KEYNES, ThE GENERAL THEORY OF EMPLOYMENT, INTEREST AND M ONEY 154-56 (1936). A dmittedly, in practice, the 'pure' cases of 'pure' sentiment and bad economic developments may be hard to find. I stylize the distinction between sentiment and bad economic developments to more sharply delineate between investor irrationality and rationality. Certainly some, and perhaps even many, commentators would attribute both investor skittishness and confidence largely to irrationality. See, e.g, Blustein, Spread, supra note 8, at E 4 (quoting an Institute of International Finance study as asserting that "spreads fell much further than can be explained by changes in economic fundamentals."). Blustein characterizes investors' reactions immediately after the inception of the A sian crisis as a rush "for the exits en masse. . .after [they were] suddenly. . .seized by pessimism." For purposes of my analysis, while I acknowledge that there may be an irrational component to investor sentiment, I also minimize its size in order to make the more difficult case for investor rationality.

28. See Section III.A, infra, for a discussion of pricing methodology in finance theory.

29. Richard Thaler, one of the leading proponents of the behavioral approach in finance, labels investors who are irrational in systematic ways as "quasi-rational;" the "irrational" investors I discuss would be "quasi-rational" in Thaler's terminology. See RICHARD THALER, QUASI-RATIONAL ECONOMICS 241 (1991). 
"incorrect" prices. Investors might irrationally overreact to recent crises by demanding too high a discount, and irrationally underreact to periods of calm by accepting too low a discount. ${ }^{30}$ Or compensation arrangements, or regulatory regimes, might lead even rational investors to maintain a certain level of emerging markets investments, even if they had to pay incorrect prices to do so. But arbitrageurs"smart money" - should be available (and inclined) to move prices back towards the correct levels; any mispricings thus should be shortlived, small, or both. ${ }^{31}$

This A rticle proceeds as follows. In Section II, I briefly trace investors' reactions to political risk in four recent crises, and describe political risk. In Section III, I revisit the standard finance theory treatment of risk. ${ }^{32}$ Finance theory assumes that we know each possible outcome, and the payoff and probability associated with each outcome. R isk is then determined by arithmetic. This assumption, while obviously wrong, arguably works sufficiently well to price securities in most cases. I argue, however, that there are certain risks, including political risk, for which payoffs and probabilities are suffi-

30. See, e.g., Cass Sunstein, The Future Of $L$ aw A nd E conomics: L ooking Forward: Behavioral A nalysis of L aw, 64 U. CHI. L. REV. 1175, 1183-84 (1997) (discussing “unrealistic optimism" and "overconfidence"); Milton Friedman \& L. J. Savage, The U tility A nalysis of Choices Involving Risk, 56 J. POL. E CON. 279, 285-86 (1948) (discussing overestimation of bad outcomes). See generally, THALER, supra note 29. See also A mos Tversky \& D aniel K ahneman, J udgement U nder U ncertainty: H euristics and Biases, 185 SCIE NCE 1174 (1974), discussing the "availability heuristic." If an event is more "available" - that is, comes readily to mind-it will loom large in probability assessments. If a person knows several people who have recently had heart attacks, he may overestimate the likelihood of heart attacks in the general population. A nd surely the A sian and Russian crises and other notorious events for a time make memories of political risk more "available." But a crucial point of the behavioral work is typically that these assessments are incorrect. There is some "fact of the matter" such as the actual rate of heart attacks in the general population against which the person's assessment can be judged and found correct or not. By contrast, in my account there is no corollary to "the actual rate of heart attacks in the general population." Intuitively, we think that some assessments as to political risk and other "uncertain" matters would be "wrong," even though it is hard to articulate how we would assess something as "right" or "wrong" except as against a "fact of the matter." Indeed, there is no "fact of the matter" as to most things investors assess, in the way there is about the rate of heart attacks or other "natural" phenomena. N evertheless, remarkably, we can usually speak intelligibly as though there were. See Section III.C, infra.

31. I argue in Section IV.D, infra, that arbitrageurs might not return prices of politically risky securities to "correct" levels in as quick or complete fashion as they would for securities involving less uncertainty.

32. See generally RONALD J. GILSON \& BERNARD S. BLACK, THE LAW AND FINANCE OF CORPORATE A CQUISITIONS 81-134 (2nd ed. 1995) (explaining risk, diversification, and asset pricing models, including the Capital A sset Pricing Model); See also RICHARD A. BREALY \& StewART C. MyERS, PRINCIPLES OF CORPORA TE FINA NCE 976-77 (5th ed. 1996) [hereinafter BREALEY \& MYERS]. 
ciently ill-understood that the standard model works less well. These "risks" rise to the level Frank K night characterized as "uncertainty." In Section IV , I consider how investors react in the face of uncertainty. Investors do not know-and know that they do not know-what the future holds. They do know, however, that the future may be perilous. D ramatic events falling within the "class" of political risk occur periodically, but at widely varying intervals; investors will cycle between skittishness and confidence, as new events cause significant revisions to their beliefs and assessments. Investors' assessment methodologies thus take into account the heterogeneity of political risk. In sum, politically risky securities will not be "mispriced"; however, the standard finance models will not readily compute the "correct" price. Section IV also considers broader implications of uncertainty for Modigliani and Miller's capital structure irrelevance theorem. ${ }^{33}$ Section $V$ concludes.

\section{POLITICAL RISK ${ }^{34}$}

\section{A. H istory and R ecent $E$ vents}

In the Latin A merican debt crisis of the 1980s, sovereigns and firms defaulted on loans made by foreign banks. Latin A merican firms found it difficult to attract foreign investment from investors other than "yield-chasing" speculators offering very unfavorable terms. O ne response was to create a transaction structure, future flows securitization, which insulated foreign investors from some measure of political risk. This transaction structure segregates a firm's foreign currency cash flows from the firm, and indeed, from the firm's home country; foreign investors are repaid from those cash flows. The cash flows easiest to segregate from a firm's home country are those not yet in existence, the firm's "future flows." ${ }^{35}$

33. See generally Franco M odigliani \& M erton H. M iller, The Cost of Capital, Corporation Finance and the Theory of I nvestment, 48 A M. E CON. REV. 261 (1958).

34. M y discussion is adapted from $\mathrm{H}$ ill, L atin A merican Securitization, supra note 2 .

35. The structure minimizes investors' exposure to political risk in several ways. First, payments on the securitization securities come from cash flows that never enter the emerging market country's borders. The risk of sovereign interference thus should be smaller and easier to quantify. Indeed, a sovereign has fewer ways to interfere with payments on future flows securitization securities than payments on most other types of securities. Once the goods or services have been exported, sovereign interference becomes more limited and difficult; the sovereign's only choice may be to restrict export of the product or service which is to generate the future receivable. 
The transaction structure helps assuage investors' fears about political risk. A s I explain in the next subsection, political risk encompasses a range of possible events. It might mean that a firm will have difficulty obtaining foreign exchange or sending it out of the country; that the repayment obligation, or some other important aspect of the transaction with a foreign investor, will not be enforced; or that political, legal or economic factors will make it difficult for the firm to obtain sufficient funds to timely meet its obligations. The structuring complexity of future flows securitization transactions is enormous. Consider, in particular, the multiple jurisdictions involved, as well as the conceptual and legal difficulty of creating rights and interests in assets not yet in existence. Moreover, many of the transactions contain elaborate quality and credit-enhancing mechanisms. Transaction volume is significant, ${ }^{36}$ suggesting that investors must be quite fearful of political risk.

The first emerging markets securitization transaction was as safe as such a transaction conceivably could have been. It involved dollardenominated receivables owed by $A T \& T$ to the Mexican government-owned telephone company, TelM ex. ${ }^{37}$ Although the receivables were not yet generated when the transaction was consummated, future generation of the receivables turned almost exclusively on people in the $U$ nited States continuing to make phone calls to M exico in sufficient volume- a very high probability event.

O nce this transaction had been completed, investors were ready to consider other, less gilt-edged transactions, where the foreign obligor was a bit less venerable or the goods or services were perhaps less certain to generate receivables in the future. Simpler structures became possible for many issuers. Then, in late 1994, M exico experienced a financial crisis in which its currency was devalued by forty percent. $^{38}$ This crisis made foreign investors "flee to quality" but the

transaction specifies in detail each step involved in generating the receivables and paying the investors; sovereign interference is therefore likely to be quite visible. Furthermore, sovereign interference might require pursuing funds in foreign jurisdictions which pride themselves on being commerce-and-investor friendly. Often, a pool-the obligor on the securitization securities- is located in an offshore haven, such as the Cayman Islands. A sovereign would presumably conclude that attempting to recover funds located in a such a jurisdiction would be costly and probably futile. In sum, investor exposure to political risk is minimized. Investors may be more exposed to one particular component of political risk, namely export-related risks. Still, their exposure is less than it would be with a direct obligation of the firm.

36. See H ill, L atin A merican Securitization, supra note 2, at 294.

37. I discuss the TelM ex transaction in $\mathrm{H}$ ill, $\mathrm{L}$ atin A merican Securitization, supra note 2 , at $115-16$.

38. See Richard Halstead, West Braces for A sia Fallout, INDEPENDENT (LONDON), Aug. 
flight was comparatively brief. Soon, spreads over Treasury bonds fell again as investors' memories faded.

$M$ ore recently, world markets, and particularly emerging markets, have been affected by crises in A sia and R ussia. The A sian crisis began in J uly of 1997 when Thailand abandoned efforts to defend its currency, the baht, and the baht's value declined dramatically. ${ }^{39}$ Since then, many A sian economies have been in crisis. This spring, political and economic problems in R ussia began to command world attention; ${ }^{40}$ in addition to the A sian flu, there is now a crisis in R ussia, with the R ussian economy (and arguably, the Russian government) nearing collapse. ${ }^{41}$

Since the A sian crisis began, many Latin A merican countries have also experienced volatile financial markets. U ntil this spring, it had appeared that their cases of "A sian flu" might be comparatively mild. ${ }^{42}$ However, at this writing, the compounded effect of the two crises, together with underlying domestic weaknesses, appear to have taken their toll: market volatility and associated economic turbulence seems to be increasing in all emerging markets, including those in $L$ atin A merica. ${ }^{43}$ Developed country financial markets, too, have been volatile: indeed, on A ugust 31, 1998, the D ow J ones Industrial A verage dropped 512 points. ${ }^{44} \quad M$ any investors are again looking back with regret to the narrow spreads they charged on their securities, being more wary in the present, and vowing not to forget so quickly in the future. A t some point, though, investors will likely return to the market, and the cycle will begin again.

\section{B. Political R isk}

Political risk is nowhere canonically defined. $R$ ather, it is a large, amorphous category. ${ }^{45}$ It contains "sovereign risk", in this con-

31, 1997, at 1; Financial Sector and Pension R eform, LA TIN FIN., M ar. 1997, at M 35, available in LEXIS, N ews Library, L atfin File.

39. See B lustein, Investors R econsider B ig B ets, supra note 16.

40. See, e.g., Paul B lustein, A sia J itters, supra note 5.

41. See Blustein, Financial Crisis, supra note 4.

42. See supra note 5 .

43. See Blustein, Financial Crises, supra note 4. See also A Shaky Week for the World's Stock M arkets, NEW Y ORK TIMES, A ugust 30, 1998. The article consists of a chart setting forth the dramatic declines in many of the world's stock markets; today, the chart would be even more dramatic, as many markets have fallen even further since the date of the article.

44. See R obert M cF adden, The M arket Turmoil: Voices; 'It's D isturbing, To Put It M ildly,' But Investors Say They'll H old O n, NEW Y OR K TIM ES, Sept. 1, 1998 at A 1.

45. Consider, for example, one popular approach to appraising political risk, the International Country R isk Guide, created in 1980 by the editors of International R eports. See R obin 
text meaning the risk that the sovereign will interfere with a firm's ability to pay its investors as promised. It also contains various political, economic and country-specific risks. Perhaps the best one can do, other than making a laundry list, is to articulate the underlying concept of virtually all political risks: risks associated with business or investment in a country which would not be present in another country with a more stable and developed business and economic climate and regulatory regime.

The classic political risks include expropriation or nationalization, where a sovereign simply takes property without compensation. A s one commentator noted,

[o]nce the quintessential political risk was epitomized by the sudden rise to power of a new leader, perhaps an aggressive young army colonel, or an earnest guerrilla in army fatigues. Committed to the greater glory of the country or the proletarian revolution, he would nationalize your company, expropriate your property and freeze your financial assets.

A notorious example of nationalization was Chile's 1969 nationalization of A naconda Copper, a U.S. firm. Chile offered the firm's

L. Diamonte, John M. Liew \& Ross L. Stevens, Political Risk in Emerging and Developed Markets, FIN. A NALYSTS J., MAY/J UNE 1996, at 71 ("Banks, multinational corporations, importers, and exporters, among others, use the ICR G model to determine the risks of operating in, investing in, or lending to particular countries"). A country's political risk score is computed by weighting the following individual scores:

a) E conomic Expectations versus R eality (12\%)

b) E conomic Planning F ailures ( $12 \%$ )

c) Political L eadership ( $12 \%$ )

d) External Conflict (10\%)

e) Corruption in Government ( $10 \%$ )

f) Military in Politics (6\%)

g) L aw and O rder Tradition (6\%)

h) R acial and Nationality Tensions (6\%)

i) O rganized R eligion in Politics (6\%)

j) Political Terrorism (6\%)

k) Civil War Risks (6\%)

l) Political Party D evelopment ( $6 \%$ )

m) Q uality of Bureaucracy (6\%).

Id. at 75,76 .

See also Brealey \& MYERS, supra note 32, at 967-77; STANDARD \& POOR'S, Structured FinanCe Ratings: SeCURITIZATION IN LATIN America 27-28 (1997); David A. JOdICE, POLITICAL RISK A SSESSMENT 5-6 (1985); Claude B. Erb et al., Political Risk, Economic Risk, and Financial Risk, FIN. A NALYSTS J., Nov./D ec. 1996, at 6. Some definitions of political risk are broader than others; definitions also vary in degree of precision. For purposes of this A rticle, I will define political risk quite broadly, perhaps sacrificing some degree of precision.

46. See generally Shapiro, supra note 19, at 54 . 
owners much less compensation than the firm was worth. ${ }^{47}$ Countries also expropriate their own citizens' wealth. For instance, Peru nationalized its banks in $1987 .{ }^{48}$ Other classic political risks are "creeping" expropriation as well as political violence. ${ }^{49}$ More recently, investors worry more about other political risks, specifically, a country's imposition of currency and exchange rate restrictions, and failure to enforce or respect agreed-upon property and contract rights. $^{50}$

O ther notorious examples where unexpected events caused investors to suffer spectacular losses include the following. When A yatollah K homeni ousted the Shah, Iran implemented a series of nationalization initiatives applicable to foreigners' property. ${ }^{51}$ M exico announced it would not pay its debts in 1982 and set off a regional crisis. $^{52} \mathrm{H}$ istory seemed to be repeating itself with the peso crisis of 1994, when M exico's currency dropped precipitously. ${ }^{53}$ Other examples include V enezuela's imposition of exchange and currency controls in 1994, precipitated by a collapse in its banking system. ${ }^{54} \mathrm{~A}$ nd, most recently of course, the A sian and R ussian crises have struck. ${ }^{55}$ L ess dramatic, but still troubling for investors, was the Chinese government's precipitous termination in 1995 of MCDonald's twenty-

47. Chile: Controversial Copper N ut Nationalization, LA TIN A M. NEWSL., July 4, 1969, at 212, available in LEXIS, N ews Library, N witrs File. The O verseas Private Insurance Corporation (OPIC), an agency of the U.S. government involved in insuring against political risk, paid out $\$ 350$ million to the owners of the company. OPIC was eventually able to recover $\$ 140$ million from the Chilean government. See Edward T. Hearn, U.S. Insurer Points to E astern E urope; Some Business Risk Factors Covered, CHICA GO TRIB., Mar. 11, 1990, at sec. 7, 5. My analysis does not expressly deal with insurance as a response to political risk. Investors will, of course, pay more for insured securities than uninsured ones. The higher amount investors will have to pay for insured securities, and indeed, whether firms will obtain insurance for their securities, will reflect where investors are in the cycle of sentiment.

48. Fights On O ver Peru B ank Policy, CHICA GO TRIB., O ct. 13, 1987, at sec. 3, 5.

49. "Political violence" consists of violent acts undertaken with the primary intent of achieving a political objective.

50. See Shapiro, supra note 19. Shapiro's sources differ about the situation today. Some believe that today's risks are different, and smaller. O thers caution not to "ignore the old fashioned political risks. They continually appear and reappear in different parts of the world." Id.

51. Donald A. Wendon, Jr., Nationalization and Iran's Race A gainst Time, MIDDLE E. EXECUTIVE REP., Sept. 1979, at 3, available in LEXIS, N ews Library, M deast File.

52. H arvey P. Shapiro, A L ess D ismal Scenario, IN STIT. INVEST., Sept. 1997, at 110.

53. See note 38 and accompanying text, supra.

54. Foreign Investors G ive V enezuela a Wide B erth, R euters Fin. Serv., M ar. 7, 1996, available in LEXIS, Busfin Library, R eufin File.

55. See discussion at Part II.A, supra. 
year lease for a site in B eijing. ${ }^{56}$ The Chinese government eventually paid M cD onald's $\$ 13.2$ million in compensation, but the dispute took two years to resolve. ${ }^{57}$

A mong investors' greatest fears may be the ascension to power of a figure like former E mperor Bokassa of the Central A frican R epublic. He spent in excess of $\$ 20$ million, an amount representing a significant portion of his country's foreign reserves, to give himself a grand coronation on a solid gold throne. ${ }^{58} \mathrm{He}$ was deposed and later

56. See Thomas L. Friedman, Fed Up, N.Y. TIMES, Mar. 4, 1996, at A 29; See also Eric Margolis, Burger Wars in Beijing, TORONTO SUN, Mar. 16, 1995, at 12, available in LEXIS, News Library, Torsun File.

A t B eijing's hottest retail location-the corner of W angfujing and D ongchan'an A venues-sits a lonely, beleaguered MCD onald's, surrounded by demolished buildings. This, the world's biggest burger emporium, is the unlikely battleground between $E$ ast and West. MCD onald's thought it had a long lease until a Chinese consortium, with strong government connections, bought the sight and ordered the restaurant out to make way for a major shopping center. The M CD onald's people screamed blue murder. The western media, which usually bash $M C D$ onald's for stripping rain forests and nutritional incorrectness, this time have championed R onald M CD onald. M CD onald's ouster, combined with widespread Chinese counterfeiting of foreign videos and software, provoked a storm of anti-Chinese resentment. Chinese, thundered the media Id. and politicians, are a nation of crooks.

A nother article noted:

[p]rotecting a brand name in the China market often resembles a mission impossible. A bogus Chinese breakfast cereal product called Kongalu cornstrips has a trademark and packaging identical to that of Kellogg's cornflakes. A small Chinese computer manufacturer, M r. Sun, has appropriated the trademark of Sun M icrosystems for its machines. A nd mineral-water drinkers in China can enjoy Pabst B lue R ibbon W ater.

L ouis K raar, The Risks A re Rising In China: Take A n A iling Patriarch, Inflation, Rampant Corruption, A nd A Culture That Considers Counterfeiting Cool, A nd What $\mathrm{H}$ ave $\mathrm{Y}$ ou G ot? A Pile of Potential Problems, FORTUNE, M ar. 6, 1995, at 180.

57. See Friedman, supra note 56 .

A nother example involves India:

J ust as foreign investors have been waking up to the idea that India is open for business, local politicians have started putting up the closed signs-literally, in the case of KFC, better known as K entucky Fried Chicken. On N ovember 11th, health inspector in Delhi closed the recently opened branch of KFC. They had discovered two flies and some uncollected rubbish. By local standards, this is a miracle of cleanliness: there are more flies in the parliament building's cafeteria or the press club in D elhi. $B$ ut $\mathrm{D}$ elhi's local government is run by the $\mathrm{H}$ indu-nationalist $\mathrm{B}$ haratiya J anata Party (BJ P), which views Colonel Sanders and his chickens as cultural imperialists. In shutting the new restaurant it was simply following the example of the Janata $D$ al government in the southern city of Bangalore, which closed KFC's first branch in India two months ago, citing impermissibly high levels of monosodium glutamate in the chickens.

Is I ndia O pen for B usiness?, E CONOMIST, N ov. 18, 1995, at 37.

58. See Emperor Bokassa I Crowned, FACTS ON FILE NEws DIG., Dec. 10, 1977, at 946 D 2, available in LEXIS, N ews L ibrary, Facts File; J ean Pierre M assamba-N golio, Former Cook Says Bokassa A te Human Body Stuffed With Rice, Reuters Ltd., M ar. 3, 1987, available in LEXIS, N ews L ibrary, R euwld File. B okassa may seem extreme, but one commentator characterized subsequent history as being even worse. The commentator, writing in early 1995, described the situation in parts of West A frica as "a postmodern barbarism unconnected to any 
tried for cannibalism; his chef testified to having stuffed bodies with rice and served them to B okassa. ${ }^{59}$ B okassa's regime was not likely to be solicitous of firm-investor bargains. Might another comparable person succeed in taking over another country? It may not be likely; however, investors may not feel comfortable concluding that it is too remote to warrant concern. More generally, most of the dramatic political risk stories seem unlikely, but how confident can we be that they may not become more likely? Investors typically will not invest in countries where the ascension of a Bokassa-like figure would be considered conceivable, except at enormous "Iemons" discounts; still, such events are part of the overall picture of political risk investors must assess.

\section{ON RISK AND UNCERTAINTY}

\section{A . Pricing Securities: The Standard M odel}

In the standard finance model, ${ }^{60}$ investors compute how much they will pay for each security by computing the security's expected return and covariance with the market portfolio. ${ }^{61}$ In the model, all the elements of these computations are known-indeed, everything about the future is known except which state of the world will happen. Each possible outcome is naturally linked to a payoff which is in turn naturally linked to a probability. E ach payoff is multiplied by its probability; each payoff/probability product is added to yield expected return. Indeed, the classic paradigms of risk are lottery tickets and coin tosses. In both cases, the payoffs (or, in the case of the coin

A frican past. The $U$ ganda of I di A min and the Central A frican 'E mpire' of the egregious J eanB edel B okassa seem rational enterprises compared with the inadvertent and apocalyptic nihilism practiced [in parts of West A frica] and in R wanda." William Pfaff, A N ew Colonialism? E urope M ust G o Back Into A frica, ForEIGN A FF., J an. 1995, at 2.

59. See J ean-Pierre B golio, "B okassa Testifies: 'I am not a cannibal,'” U PI, Mar. 2, 1987; available in LEXIS, News Library, U pi File; R obert Chalmers, People for Tea, INDEPENDENT (LONDON), M ar. 22, 1991, at 17.

60. GILSON \& BLACK, supra note 32, at 101-34; BREALEY \& MYERS, supra note 32, at 179-87. The Capital A sset Pricing M odel, or CA PM, is the dominant model; in any event, the formula for its main competitor, A rbitrage Pricing Theory, includes payoffs, probabilities, and market covariances, in addition to other elements. See, e.g., BREALEY \& MYERS, supra note 32 , at $190-91$.

61. A security's covariance with the market portfolio reflects how much the security can be expected to change in value when the market increases some percent in value. Covariance is a function of the "systematic," or market, risks this security involves. Systematic risks are risks of the market as a whole. Risks that are not "systematic" are "unsystematic," that is, particular to a firm or group of firms. BREALEY \& MYERS, supra note 32, at 156. 
toss, outcomes) are known, as are the associated probabilities. In the case of the lottery, the possible outcomes are the payoffs; the associated probabilities are, for a lottery in which there is one winning ticket and one hundred tickets in all, one percent for the winning payoff and ninety-nine percent for the losing payoffs. ${ }^{62}$

\section{B. D ifficulties with the Standard M odel}

In the real world, of course, payoffs and probabilities can only be estimated. In the typical case involving developed markets-that is, where political risk has been considered negligible ${ }^{63}$ - the estimates of payoff and probability are often good enough, as I will argue in section III.C. ${ }^{64}$ For political risk, estimates are much worse ${ }^{65}-$ much to

62. In the model, a security's covariance is known as well. The model also assumes that investors can construct and buy a portfolio of securities (the "market portfolio") which tracks the performance of the market. Buying the market portfolio permits the investor to diversify away all risks particular to firms or groups of firms; as a result, investors bear only systematic, or market, risk, the amount of which is measured by the covariance of each of their securities with the market. Thus, the investor knows how to diversify away certain risks, and has a formula with which to price the remaining ones.

63. However, as the A sian and Russian crises have shown, increasing globalization of markets means that political risk may have become more important for developed country firms and markets: markets all over the world have exhibited enourmous volatility in response to the crises. The effects continue to be felt worldwide. See e.g., Blustein, Financial Crises, supra note 4 . The causal link between the A sian crisis and volatility in developed country markets has been clearer than the link between the R ussian crisis and such volatility; still, the R ussian crisis has undoubtedly been a significant contributor to the volatility.

64. Estimates of covariance with the market portfolio may be good enough as well. Indeed, droves of financial analysts are continuously computing and recomputing these numbers. Of course, they can only compute past covariances; the premise is that future covariance will resemble past covariance. It should, at least sufficiently well to serve as a basis for setting prices, if covariance falls within Knight's category of "statistical probability" rather than his category of an "estimate." See Section III.C, infra. Finally, selecting a portfolio sufficiently close to the market portfolio may very well be feasible, given the advanced state of finance research. Thus, investors should only be exposed to the market risk; they have diversified away all other risks. A t least, this would have been the story told, before the recent tumult in world markets. The crash of 1987 caused some rethinking of finance theory; the present events may cause some further, and perhaps more dramatic, rethinking.

65. A pplication of the remainder of the model is also uneasy. Indeed, the concepts of "market," "systematic risk" and "unsystematic risk" may not be readily applicable. What is the relevant "market" for which investors would need to construct a market portfolio? Thus far, while the trend is towards greater integration of markets, most investors invest locally; capital markets are national, rather than international. See BREALEY \& M YERS, supra note 32, at 970. See also Martin S. Feldstein, Global Capital Flows; Too Little, Not Too Much, EconomIST, J une 24, 1995, at 72 ("A Ithough most of the legal barriers to international capital mobility are now gone, the world capital market remains essentially segmented along national lines."). See also J ohn J. Schmitz, The Heritage of International Finance, 13 CA NA DIA N J. A DM IN. SCI. 163 (1996) available in LEXIS, Busfin Library, A bi File. ("The majority of finance theories are not explicitly single-country theories, because they are implicitly intended to be universal theories. 
the consternation of investors, because the risks are potentially catastrophic. A s I discussed in Section II.B, there are many dramatic examples of political risk where investors have incurred huge losses due to some precipitous, unexpected event. To apply the standard finance model's pricing formula, investors need estimates of payoffs and probabilities; as I will argue below, for political risk, their estimates are simply not "good enough." ${ }^{16}$

Why are the estimates not good enough? B ecause political risk is quite uncertain. The events comprising the class are extremely heterogeneous, vastly complicating the task of assessing probabilities and payoffs. Of course, heterogeneity and uncertainty are matters of degree: most matters investors assess are uncertain, and belong to heterogeneous classes. But the degree of heterogeneity and uncertainty is greater for political risk: E stimates of payoff and probability are not of a caliber to permit straightforward application of the standard finance model's pricing formula. ${ }^{67}$

Nevertheless, they do not explicitly acknowledge in their assumptions or theoretical developments the existence of differences between nations." ). Schmitz concludes that neither international CA PM nor A PT is "capable of capturing the complexity of international asset markets." Id.

Even if we could determine what the relevant market was, constructing a "market portfolio" would present its own difficulties. We would have to determine which risks were systematic in that market. A nd even if all these questions could be answered, would political risk be systematic or unsystematic? Some actions might affect only one firm; other actions might have much broader effects. Indeed, what investors do know about political risk likely does not include how to diversify the risk away. Some political risk might be systematic, and thereby not amenable to diversification. There might be no relevant "market" as to which a market portfolio diversifying away the systematic risk could be constructed. Or there might be such a market, but constructing the market portfolio might be impossible. Thus, ready applicability of CA PM or another pricing model to emerging markets investment is not straightforward. See also Feldstein, at 72 (noting that "[t]he reluctance of portfolio managers to invest more in foreign securities may reflect a broader measure of risk than the historic covariances on which the economic analysis is based, including a concern about low-probability events, such as repayment default or currency non-convertibility.").

66. "Good enough" for many securities may simply mean good enough with respect to a small, readily constructed portfolio of securities, rather than for each security in the portfolio; in the aggregate, the errors would largely cancel each other out. But with politically risky securities, even the estimate for the group would not be good enough-the estimates for each security would be worse, and the aggregate errors might very well not cancel each other out. For analytic ease, so long as estimates for a constructible portfolio are good enough, I speak as though estimates for each security in the portfolio were good enough.

67. A nother way to articulate my thesis uses the terminology of the A sset Pricing Theory: political risk is "priced." In an A PT-type model, the pricing of politically risky securities would include additional factors, perhaps one reflecting political risk itself, or the degree of "estimation risk" by which the payoffs and probabilities for politically risky securities would be expected to be in error. I am not suggesting that either A PT, or CA PM, would yield incorrect prices for politically risky securities. Rather, I am making a more modest claim, that use of the models to price 


\section{Uncertainty}

In Risk, U ncertainty and Profit, Frank K night distinguishes three types of "probability": (1) a priori probability, (2) statistical probability, and (3) estimates. ${ }^{68}$ A priori probability requires "[a]bsolutely homogenous classification of instances completely identical except for really indeterminate factors" ${ }^{\prime 69}$ coin tosses and lottery tickets are the paradigm examples. M ost real-world events are not repeated iterations of one another the way coin tosses and lotteries are; thus we can have less confidence in our assessments of probabilities as to such events than we can about coin tosses and lotteries. ${ }^{70}$ Indeed, statistical probability lacks such homogenous classification; thus, "we cannot ... calculate the true probability from external data, but must derive it from an inductive study of a large group of cases." ${ }^{71}$ Life expectancy rates are examples of statistical probabilities. ity:

A $n$ estimate is to be distinguished from either type of probabil-

[t]here is no possibility of forming in any way groups of instances of sufficient homogeneity to make possible a quantitative determination of true probability ${ }^{72} \ldots$

Where all we have are estimates, we do not have "risk;" rather, we have "uncertainty." A ccording to K night, uncertainty is "one of the fundamental facts of life." 73

The practical difference between ... risk and uncertainty, is that in the former the distribution of the outcome in a group of instances is known (either through calculation a priori or

the securities ex ante would be clumsy, difficult, and perhaps, intractably, more 'art' than 'science.' The process would scarcely be mechanical, as one might more typically expect from a quantitative model. As to APT, how would we go about estimating the political risk or estimation risk "factor"? I discuss difficulties in applying CA PM to politically risky securities in note 65 , supra, and accompanying text. M oreover, as I discuss in Section IV . B, supra, the models do not capture how investors take account of uncertainty; to the contrary, the models, by implicitly assuming perfect information, or at least, information far superior than exists in the real world, gloss over differences in degree and kind among different types of risks and uncertainties.

68. K night thinks that the first two are "true" probabilities and the third is not. I gloss over this distinction, because my analysis deals only with K night's third category, "estimates." Thus, my analysis is consistent with the Bayesian view that purported statistical probabilities are actually estimates. See K NIGHT, supra note 22, at 224-25, 231.

69. Id. at 224.

70. See Einhorn \& Hogarth, supra note 23 , at $43-46$. E inhorn and Hogarth note that "when assessing uncertainty in real world tasks, the precision of the gambling analogy can be misleading." Id. at 42, 43.

71. Id. at 230-31.

72. KNIGHT, supra note 22 , at 231 .

73. Id. at 347. 
from statistics of past experience), while in the case of uncertainty this is not true, the reason being in general that it is impossible to form a group of instances, because the situation dealt with is in a high degree unique. ${ }^{74}$

$\mathrm{K}$ night describes various ways of dealing with uncertainty, including "increas[ing] our knowledge of the future through scientific research and the accumulation and study of the necessary data." 75 $\mathrm{K}$ night also considers consolidation of uncertainties (including through insurance), specialization in risk-bearing, and increasing control over the future. ${ }^{76}$ Through these techniques and others, investors are able to compute probabilities and payoffs sufficient to price standard risks. But these techniques are not sufficient to price political risk (or politically risky securities) with precision, at least at present. The techniques are used and do help to reduce the uncertainty enough that investors are sometimes willing to buy politically risky securities. B ut the uncertainty is not eliminated; significant uncertainty remains.

Compare the predictions one can make about life expectancy with those one can make about the course of the A sian and R ussian crises. N otwithstanding considerable heterogeneity among people's diseases-that is, notwithstanding that people's diseases are much less like one another than lottery tickets and coin tosses- we know quite a bit about, and make very good predictions about, how long people will live, and from what causes they will die. A ssume we designate payoffs that very roughly correlate to life or death or various diseases: investors in politically risky security $X$ are repaid (a) in full; (b) fifty percent; or (c) zero percent. How would we determine which outcomes led to those payoffs, and the probabilities of those outcomes? With coin tosses, we know the laws under which the probabilities are determined. W ith life expectancy, we have a great deal of data from which to determine probabilities. W ith political risk, we have data as well, but the data is not readily categorized. What do we learn about the future from the reign of $E$ mperor Bokassa, the expropriation of A naconda Copper, or the Mexican peso crisis? We clearly learn something. But we do not learn anything that helps us predict the future nearly as well as studying past statistics about death and disease helps us predict future life expectancy. The more heterogeneous the class, the more difficult it is to learn

74. K NIGHT, supra note 22 , at 233.

75. Id. at 347.

76. Id. at 239, 347. 
from the past; ${ }^{77}$ heterogeneity assures that even identifying an event as a member of the class is complex. D eath and disease may not constitute homogenous classes, but the classes are far more homogenous than political risk.

Consider the prospects of an established business. Investors and analysts consider their assessments of probability good enough to guide investment with a fair measure of confidence. Intuition suggests the assessment is far from mechanical; certainly, the events to be classified are not "homogeneous," much less "absolutely homogeneous." ${ }^{78}$ Still, we have arguably identified many of the salient features necessary to formulate probabilities and payoffs sufficiently accurate to yield a good assessment. Through use of the various techniques described by $\mathrm{K}$ night, the uncertainty has been reduced, such that the estimates are arguably good enough to permit ready use of our standard pricing models.

A nother feature of political risk contributes to its heterogeneity: the complex manner in which the actors involved respond to incentives. $^{79}$ What kinds of decisions will Boris Y eltsin make? How will

77. M ore generally, learning from the past requires identifying the salient features of an event-something that only becomes possible after many such events have occurred. The less homogeneous the events are, the more difficult it is to learn from experience, and the more difficult it is to have confidence that one has learned sufficiently from experience- that the lessons one has learned have been the right ones. (I discuss the difficulties of learning from experience in Why Contracts are Written in L egalese (working paper, on file with Duke J ournal of Comparative \& International $L$ aw)). Traditional accounts of information acquisition tend to obscure this problem. They treat lack of information as though it could necessarily and mechanically be remedied by an expenditure of costs. The only relevant determination is whether those costs are warranted given the benefits to be obtained. But in many cases, the benefits of additional information may not be straightforward, nor may it be clear that an expenditure of costs in fact yields additional "information" at all.

78. Indeed, homogeneity is not an inherent, passive attribute of a group of objects or events. Speaking as though homogeneity were not a constructed category is commonplacebut wrong. If $A$ is a valentine and $B$ is a tomato, are they members of a homogeneous class? The answer is not obvious. $Y$ es, if the class is objects sharing the quality of redness. No, if the class is objects smaller than a breadbox. See NELSON GOODMAN, LANGUA GES OF A RT 34-39, 71-74 (1968); K NIGHT, supra note 22, at 225-26 ("In the first place, nothing in the universe of experience is absolutely unique any more than any two things are absolutely alike. Consequently it is always possible to form classes if the bars are let down and loose enough interpretation of similarity is accepted." ). K night accepts far more than Goodman the notion that homogeneity (and similarity) is to some extent inherent. But both would agree that grouping events into classes is far from mechanical in virtually all cases.

Some classification schemes are clearly more useful, and, in some sense (although one that is quite difficult to articulate, much less defend), more "natural" than others; still, it should be recognized that they are all imposed on the items or events being classified, thus further complicating the task of assigning future probabilities.

79. M any risks respond to incentives, but not in a way that makes them appreciably harder 
the various factions in R ussia, and the various international actors, react? A $n$ investor contemplating investing in $R$ ussia would have to guess as to the future course of events in Russia. But the investor would not, and indeed should not, have much confidence in her guess-certainly, not enough confidence to invest, except perhaps at a very large lemons discount.

Consider an investor contemplating investment opportunities in Indonesia in the spring of 1998. In A pril, then-President Suharto was considering various 'responses' to the crisis his country was facing. O ne 'response,' a currency board that would tie the Indonesian currency, the rupiah, to the U.S. dollar ${ }^{80}$ was likely to motivated by Suharto's desire to enable his relatives to exchange their rupiahs at a higher rate than they otherwise could. Suharto rejected the idea, apparently in response to negative pressure from the International M onetary Fund and others: ${ }^{81}$ Indeed, the IMF thought such a board had a significant chance of leading to an economic collapse. ${ }^{82}$ How was an investor to determine the probability that Suharto would create the currency board, or take some other action, perhaps also with destabilizing potential? Or accede to the wishes of the International M onetary Fund ${ }^{83}$ The investor might have made a guess, but, again,

to classify into homogenous classes. For instance, as I discuss in Section IV .B., infra, in standard theory, one financial structure, high leverage, makes a firm more valuable by constraining its managers' ability to fritter away cash. But these effects are comparatively easy to compute. The managers' non-constrained behavior if the firm adopts some other financial structure can be compared with their constrained behavior. A s discussed in the text, political risk's response to incentives is more complex, because of the complex interactions among the many actors involved.

80. See Barry Porter \& Simon B eck, A id Banks Pressure Suharto; World B ank and ADB Follow L ead and Block A id to Indonesia, S. CHINA MORNING POST, Mar. 11, 1998, at 1, available in LEXIS, N ews Library, Schina File.

81. See Paul K rugman, Rupiah Rasputin: A Currency B oard Won't Solve Indonesia's Woes, FORTUNE, A pril 13, 1998, at 115.

82. See Porter $\&$ B eck, supra note 80 , at 1 .

83. Indeed, this formulation understates the problem, as the analysis in Section IV .A ., infra, will make clear. To apply standard finance methodology to value an investment, we have to be able to group the possible outcomes by payoff-we would have needed to know, or, more precisely, make a good enough guess for instance, not just how likely it was that former President Suharto of Indonesia adopted proposed International M onetary Fund reforms, but what the payoff to investors holding interests in Indonesian firms would have been had he adopted the reforms. Similarly, when an investor is considering investing in Russia, she must try to group the myriad possible outcomes by payoff: say, outcomes 1, 2 and 3 will lead to massive civil unrest and zero payoff: outcomes 4,5 and 6 will lead to a new pro-business leader coming in, and a very high payoff; outcomes 7, 8 and 9 will lead to continued turmoil, and the payoff will not be certain for a long while. Where the types of events involved are more standard, grouping outcomes by payoff becomes feasible: we can say, for instance, that if a product introduction is a success, the payoff to investors holding a particular interest in the firm will be ap- 
not a guess at to which she should have had much confidence. Indeed, what actually happened is that on M ay 21, 1998, after 32 years in office, during which time he had withstood many crises, President Suharto resigned. ${ }^{84}$ The currency board idea appears to have been dropped, but reaction to the crisis, both by Suharto's successor, President $\mathrm{H}$ abibie, and the international community, is still evolving. Whatever else hindsight may tell us about what happened in Indonesia, it also tells us that the skittish investor, who knew she did not know much about what would happen, was right.

The A sian and R ussian crises may be extreme, but political risk not infrequently involves extreme situations with potentially extreme consequences. Indeed, for political risk, an investor can have far more confidence that a consequence could be disastrous than that its probability is remote.

\section{INVESTOR REA CTION TO POLITICAL RISK}

\section{A. Investors' M ethodology}

The foregoing argues that investors have difficulty pricing political risk. How might this lead to cycling?

There are crises, followed and preceded by periods of apparent calm. Investors update their beliefs with each new piece of information. B ecause the investor often has more reason to think the future will resemble the recent past than that it will resemble the more distant past, the updating will often give significant weight to the new information .

Indeed, what makes political risk especially difficult to predict is that our store of knowledge does not cumulate efficiently. Consider again business failures, many of the business prospects in developed markets more generally, or life expectancy: as new events occur, our confidence in our knowledge increases. But what does the occurrence of an "event," such as the A sian or Russian crisis, suggest about political risk prospectively? For all the investor knows, the world has now changed permanently, with political risk assuming a more prominent role. Thus, if there has been a recent crisis or upheaval, the investor will be skittish. A fter a period of calm, however, the investor may also have good reason to think that calm will prevail

proximately $\$ \mathrm{x}$. A 1.

84. K eith R ichburg, Suharto Steps D own, Names Successor, W A SH. POST, M ay 21, 1998 at 
in the moderate term. Since crises and calm alternate, so too does investor sentiment.

The problem stems from what type of event-or more precisely, class of events- political risk is. I argued above that political risk is quite heterogeneous. But the starting point of the standard asset pricing formula, "expected value," is predicated on, and indeed embeds, homogeneity. Consider a typical expected value computation: In twenty percent of the cases outcome $A$ (payoff of 1 ) will occur, in twenty-five percent outcome B will occur (payoff of 2), and in fiftyfive percent outcome $C$ will occur (payoff of 0 ). Translated, this means that if the universe were run 100 times, 20 times the payoff should be 1, 25 times the payoff should be 2, and 55 times the payoff should be 0 . The more times the universe is run, the more times the proportions should approach 20,25 and 55. But the universe is only going to run once. The payoff will be 1 , or 2 , or 0 ; the investor prices each "iteration" at .7, even though the payoff will never be .7, because he treats an iteration as one of many. A nd doing so is not only the best the investor can do, but also "correct," even though there will not be multiple iterations. The events are sufficiently homogeneous that they can be treated as iterations of one another.

The investor pricing political risk cannot use this methodology nearly as mechanically. Political risk can be characterized as a class; however, each "event" scarcely seems like one iteration of many. A $n$ investor might plausibly react by making more broad-brush assessments: E ither the risk is to be taken, or it is not. The risk is only taken if it is acceptably low (or the lemons discount is very high). The assessment does not distinguish between, for instance, 23\% probability of a particular outcome and $27 \%$, or for that matter $60 \%$ and $70 \%$. Indeed, for events in heterogeneous classes, what would such numbers mean? We only really know what they mean for truly homogeneous events such as coin tosses. The less homogeneous a class of events is, the more difficult it is to construct such honed probabilities. How do we characterize the event we suppose would happen $23 \%$ of the time? Where events within a class are more heterogeneous, as is the case for political risk, the imagination has no ready use for these increments.

The result is to exacerbate the cycling of investor sentiment.

\section{B. The Cycle}

Immediately post-crisis, after some dramatic and unfavorable event has occured, investors are quite skittish; as discussed above, the 
world could have changed permanently, or at least in the short-tomoderate term, such that instability is now more common. Few investors will enter the market. Those that will are likely to be "bottom-fishers," specializing in risky emerging markets or speculative investing. ${ }^{85}$ They will demand a high lemons discount that accords with their worst case estimate. Thus, emerging markets firms may delay seeking financing, or seek financing from domestic sources; transaction volume, particularly in foreign markets, should be low.

A s time passes without incident, word will spread, aided by investment bankers making the "M ichael M ilken" argument: The lemons discount is higher than the risks warrant. More investors, including more conservative investors, will enter the market, and prices will fall. Because there will always be some lemons discount for political risk, the securities will be seen as offering an attractive combination of safety and yield. Moreover, if investors' domestic market rates are low, they may be particularly aggressive in seeking higheryielding investments. ${ }^{86}$ F urther, as markets become more global, the standard for a diversified portfolio increasingly includes emerging markets securities. ${ }^{87}$ Demand should increase, and the lemons discount should decrease further; supply, then, should increase, as firms seek financing to avail themselves of advantageous rates. So long as time proceeds without incident, investor confidence should be virtu-

85. See, e.g., Kerry A. D olan, Riding the Coattails of the Global Boom, ForBES, A pr. 20, 1998, at 58 (describing the investment activities of a wealthy investor, Saudi Prince A Iwaleed Bin Talal). The article asks: "Is it too soon to bottom-fish in A sia? A Iwaleed has already cast his lines there." Id. at 64. The article proceeds to describe various investments A I waleed has recently made in South Korean and Malaysian companies. The article also notes that "A sia appeals to [A Iwaleed] now because investments there fit an important A Iwaleed investment criteria: $R$ ather than be early, he favors going into a promising situation just after it has taken a bad hit- $30 \%$ to $50 \%$, preferably." Id. at 64 . A s discussed in note 5 , supra, and accompanying text, in A pril of 1998, when the articles cited in this note were written, world markets, including some A sian markets, seemed to be recovering from the A sian flu. Now, as turmoil again roils world markets, it will be interesting to see how A pril's bottom-fishers have fared, and whether they, or others, are fishing again.

86. See, e.g., I psen, supra note 19 ("Simply put, puny growth and low inflation in the developed world mean that returns there are puny in comparison to the vibrant emerging market economies.").

87. See id. at $A 1$ ("O ne of the underpinnings of the emerging-market phenomenon is that the market has now taken its place as a separate so-called asset class, which means that large institutions intent on having diversified portfolios will find it indispensable to hold some emerging market debt and equity."). A ccording to my practitioner sources, however, "indispensable" may be an overstatement: they say cautious or quality-conscious investors will not feel constrained to continue investing in emerging markets securities during times when emerging markets are unsettled. 
ally self-perpetuating. E ventually, some upheaval occurs, and the cycle begins again. And again, cycling is the best investors can do. When investors are confident, their lemons discount is low; when they are skittish, their lemons discount is high. In each case, politically risky securities are priced correctly; the discount reflects an investor's best guess.

\section{Other Explanations}

Why else might investor reaction to political risk cycle? I consider two additional explanations.

1. A gency Costs. A $n$ agency cost dynamic also may be involved. The first investor making a politically risky investment after a crash may face greater downside risk if the investment fails than he would face upside benefit if the investment succeeded. A significant volume of funds are invested by agents, such as managers of mutual funds and pension funds, on behalf of their principals, the funds' beneficiaries. These agents' best strategy may be to avoid belowaverage performance rather than to seek above-average performance. A comparable dynamic may send investors to emerging markets once the first has entered. These incentives exacerbate the cycle of investor sentiment. Investor sentiment immediately post-crisis is more skittish, and the reaction after a period of calm is more sanguine. R egulatory constraints add to the effect: many large institutional investors are subject to regulatory or legal regimes which reward conformity with other investors over taking risks. ${ }^{88}$

2. Psychological Factors. I nvestor reaction to political risk may to some extent be "irrational." Economists and legal scholars are increasingly considering how human behavior deviates from rationality. ${ }^{89}$ Investor reaction to political risk might implicate two psychological dynamics scholars have identified. Skittish investors

88. I discuss these matters in Claire A . H ill, Why Financial A ppearances M ight M atter: A n Explanation for Dirty Pooling and O ther Financial Cosmetics, 22 D EL. J . COR P. L. 141, 174-84 (1997) [hereinafter, Financial A ppearances] (discussing volume of funds managed by money managers anxious to do no worse than their peers). On investors' herd behavior, see generally GILSON \& BLACK, supra note 32, at 167, and sources cited therein. Id. See also Feldstein, supra note 65 (suggesting that portfolio managers and fiduciary committees might also "see their task as 'acting prudently' rather than maximizing a risk-adjusted return" and might therefore be reluctant to invest more in foreign securities).

89. See supra note 30 and accompanying text. 
might be overestimating political risk because of their recent memories of events falling within the class of political risk. This is called the "availability bias," meaning that the information about the recent event is "available" in a manner that increases a person's assessment of its actual probability. Conversely, confident investors might be "overconfident," underestimating the then remote-seeming, and, on this view, actually remote, likelihood of political risk. Underestimating remote risks is also a well-documented psychological dynamic. $^{90}$ Given the pattern of events falling within the class of political risk - that is, what happens in the real worldalternating overestimation and underestimation should not be surprising.

\section{Pricing of Politically R isky Securities}

I argued in section IV.B. that investors are pricing politically risky securities as well as they can-that they are pricing the securities "correctly." By contrast, both the irrationality and agency and regulatory stories considered in section IV .C. could lead investors to price such securities "incorrectly." The irrational investors might pay too much because they underestimated political risk. The investors described in the agency and regulatory cost stories might pay too much as well, when maintaining the desired level of emerging markets investments required paying too-high prices. Or both sets of investors might only be willing to pay too little: the irrational investors, because they overestimate political risk, and the agency and regulatory-cost saddled investors, because none of their peers were investing, or their regulators had discouraged or prohibited such investments. B ut arbitrageurs-investors who do not make pricing mistakes, and indeed, correct others' pricing mistakes-stand ready to correct these mistakes. ${ }^{91}$

90. Id. See also R obert A. O Isen, Prospect Theory As A $n$ Explanation of R isky Choice by Professional Investors: Some E vidence, 6 R EV. FIN. E CON. 225 (1997), available in LE XIS, B usfin Library, A sapii File (discussing one of the prominent theories in the behavioral literature, prospect theory). A mong the features of prospect theory are "an overweighting of lower probability events (but with some small non-zero probabilities being ignored) and an overweighting of high probability events." Id.

91. The mistake-correction process might not proceed as smoothly as it would in most other cases. Soon after a crisis, the arbitrageurs likely anticipate that they will shortly know more, and might hence delay their mistake-correction activities. Moreover, political risk's uncertainty might make arbitrageurs allow a greater margin for error, and they might stop their activities once a conservative estimate of the correct price had been reached. Nevertheless, on my account, pricing mistakes should be small, short-lived, or both. But my theory does not presume or require the existence of investor mistakes, or, even, the efficacy of arbitrageurs' mistake- 


\section{E . Implications for M odigliani and M iller's Capital Structure Irrelevance Theorem}

1. The Theory and Its A ssumptions. Modigliani and Miller's capital structure irrelevance theorem holds that capital structure, the way a firm chooses to finance itself, cannot add value. ${ }^{92} \mathrm{~A} s$ is well known, the theorem's assumptions are commonly violated in the real world; a financing vehicle's added value is traced to one or more violations of these assumptions.

A mong Modigliani and M iller's assumptions are (1) zero information costs and (2) implicitly, that there will be no different claims on the firm's cash flows on account of a particular financing transaction (other than the direct claim of the investor providing the financing). ${ }^{93}$ The latter assumption bears some explaining. It means that the firm's cash outflows will not change because the firm chose, for instance, debt rather than equity (except, of course, to the extent the debt payments differ from the equity payments).

As is well known, both assumptions are wrong. Information costs are positive. Information is, of course, not free. A nd a firm's cash outflows are affected by its capital structure. For instance, scholars have argued that high levels of debt discipline managers into frittering away less of a firm's cash. ${ }^{94}$

2. Information Costs. Uncertainty is particularly costly to appraise. Most firms, domestic and foreign, have some level of uncertainty, although typically the uncertainty does not have consequences as significant as those discussed for political risk. A firm might reduce its investors' aggregate information costs by confining uncertainty to a smaller part of the firm. ${ }^{95}$ I have previously made this argument about domestic securitizations done by firms

correction activities. R ather, I argue that investors are pricing politically securities correctly - that there are no mistakes to correct.

92. See generally M odigliani \& M iller, supra note 33 .

93. Statements of the assumptions include M odigliani \& M iller, supra note 33 , and E ugene F. Fama, The Effects of Firm's Investment and Financing Decisions, 68 A M E CON. REV . 272 (1978). See also Hill, L emons, supra note 6, at 1084-85.

94. See M ichael J ensen, A gency Costs of Free Cash Flow, Corporate Finance, and Takeovers, 76 A M. E CON. REV. 323 (1986).

95. Future flows securitization, done by emerging market firms, also confines the uncertainty of political risk to a smaller part of the firm; however, the case for aggregate information cost reductions is more complicated because the baseline "information costs" are hard to specify-are foreign investors part of the baseline or not? 
subject to significant uncertainties. ${ }^{96}$ More generally, confining uncertainty is one reason why a firm forms a subsidiary or affiliate to conduct activities engendering uncertainty. A nd recent financing innovations, such as stock whose value tracks a particular portion of a firm's operations rather than the whole firm (called "targeted stock") might also in part be motivated by the information cost reduction effects of confining uncertainty.

3. Financing Decision Independence. The second assumption, that a firm's cash outflows are unaffected by its capital structure, is violated by transaction structures that limit the pot of assets available to potential third-party claimants of a firm (I call such structures "pot-limiting structures"). All of the structures discussed in the previous paragraph, save targeted stock, are pot-limiting structures. Some scholars have condemned firms' abilities to use pot-limiting structures, ${ }^{97}$ arguing that a firm and its "second-party" (contractual) claimants- the two sets of parties crafting the limitations-are hiding behind legal structures to avoid paying the "full cost" of doing business. $^{98}$ On this view, the value-added to the firm is easy to explain: the firm shifts some of its costs to non-consenting third parties.

Putting aside the question of whether such structures do or do not help firms avoid the full cost of doing business, ${ }^{99}$ the structures serve another legitimate function in the face of uncertainty. The uncertainty itself imposes costs: confining uncertainty may reduce these costs, to no one's detriment, except those seeking transaction costs from the process of asserting and pressing claims. Indeed, some types of third-party claims are in large measure dynamic. The amount of damage they cause very much depends on the course the claim takes, which in turn depends on the complex interaction of the

96. See H ill, L emons, supra note 6, at 1086-93. In that article, I argued for the benefits of confining "residual-style risks" to a smaller portion of the firm. The concepts "residual-style risk" and "uncertainty" overlap, but are not identical. M ost, if not all, residual-style risks (risks associated with the firm's residual interests) will be to some degree uncertain, but there may be some uncertainties that are not residual-style risks.

97. See, e.g., Lynn L oPucki, The D eath Of L iability, 106 Y A LE L.J . 1 (1996)

98. Id.

99. On a Modigliani and M iller analysis, the firm's financing decision would indeed have affected its cash outflows, by reducing the expected outflows by the amounts no longer payable to the potential third-party claimants. Note, however, that if the firm is shifting risk to uncompensated and nonconsensual risk-bearers, the net result would be zero sum, or perhaps even negative sum if the firm behaved more recklessly knowing it could not be help responsible therefor. 
various actors and institutions involved. Scholars critical of a firm's ability to limit particular claimants' entitlements to part of the firm's assets assume that the claims are purely a function of the damage the firm does and the harm the claimant suffers. The implicit paradigm is someone who is injured or killed by the firm's negligence. But the real world is rife with examples of third-party claimants who set in motion a process able to exact damages exponentially greater than whatever harm the claimants may have suffered. O bvious examples include mass and toxic torts. ${ }^{100}$

Therefore, when a firm uses a pot-limiting structure, it may not just be playing a zero-sum game in which the losers are the third party claimants. In an efficient world, a firm should only have to pay for actual damages; amounts in excess of actual damages (such as the massive transaction costs associated with mass and toxic torts) should neither be borne by the firm nor should the firm's investors have to discount therefor. Thus, a pot-limiting structure should be positivesum insofar as it limits the pot available to pay such excess amounts, and reduces the associated cloud of uncertainty.

This analysis can be extended a step further. Consider how the use of pot-limiting transaction structures might affect the riskimposition process more generally. In my account of emerging markets future flows securitization, I argued that the transaction's effect on potential third-party claimants might make such claimants' pursuit of their claims more efficient, rather than potentially depriving them of assets to which they otherwise might be entitled. The third-party claimants at issue were sovereigns and other governmental authorities, and more broadly, the legal and regulatory "system" imposing such risks.

Indeed, the risk-or more precisely uncertainty-imposition process involved in both political risk and mass and toxic torts seems intuitively quite inefficient. The firm's burden is larger than the

100. See J ohn C. Coffee, J r., Class Wars: The Dilemma of the M ass Tort Class A ction, 95 Colum. L. Rev. 1343, 1347 n.12, 1348-49 n.15 (1995). See also D an R. A nderson, Financial and Organizational Impact of Superfund- $M$ andated $H$ azardous Waste $L$ iabilities on the Insurance Industry, 49 CPCU J OURNA L 22 (1996), available in LEXIS, Busfin Library, A bi File. ("A significant portion of the total costs is comprised of transaction costs incurred by the government, PR P's (potentially responsible parties), and insurers."). The article cites several studies. O ne estimates litigation and administration costs as "approximately 40 percent of total Superfund costs." Id. A nother estimated insurer transaction costs as "88\% of their total expenditures." Id. A third study estimated insurer and PR P transaction costs as "at least $35 \%$ of all Superfund related-expenditures." Id. See also Sean Mooney, Fickle Tort System Fogs Up Crystal Ball on G eneral Liability, 101 NAT'L UNDERWRITER (PROPERTY \& CASUALTY/RISK \& Benefits M A NA GEMENT), N ov. 24, 1997, at 47, available in LEXIS, Busfin Library, A bi File. 
benefit to the third party claimants, as the actors involved pursue their divergent interests. ${ }^{101}$ Firms' attempts to offer their investors more certainty through careful transaction structuring might make more costly and visible the third-parties' risk-imposition. To the extent the risk-imposition process is inefficient, making it more costly and visible could serve to make it more efficient. ${ }^{102}$

In sum, I have argued in Section IV.D. that securities pricing takes account of uncertainty. The foregoing suggests that transaction structuring takes account of uncertainty as well.

\section{CONCLUSION}

No one can predict the future. $Y$ et, finance theory assumes we know far more about the future than we actually do. This assumption is arguably good enough for most purposes for which it is used. I have argued that for politically risky securities, and for other risks sharing some of political risk's salient features, the assumption is not good enough. In the face of uncertainty, investors do the best they can; for political risk, the best they can do is to alternate between optimism and skittishness, as new events cause significant revisions to their beliefs and assessments. Investors know sufficiently little about political risk that they cannot "homogenize" the category in any meaningful way: they cannot help imagining that some politically risky event either will occur or it will not. When they appraise as plausible the likelihood of an event with very bad consequences, they refrain from investing; when they do not, they may invest, taking only a small lemons discount.

We may one day learn enough to fit political risk better into the standard pricing model, or to create a model better suited to the task. I make no claim that our uncertainty, or a pricing model's ability to deal with uncertainty, is intractable. ${ }^{103}$ B ut at present, it seems hard

101. In some contexts, casting a long shadow of risk, by, for instance, having a reputation for being dangerous and unpredictable, offers a payoff to the actors involved. In the context of political risk, the risk-imposers seem mostly to suffer along with the firms and their investors, for the spectre of uncertainty over and above the amount of "actual" damages they have suffered.

102. M ass and toxic tort cases will necessarily be visible, and fought to a large extent in the political arena, regardless of the efforts firms make to shield their investors from the consequences. Thus, in those contexts, my argument may have more theoretical import than practical bite.

103. In any event, we have thus far dealt sufficiently well with uncertainty that globalization of markets, and transaction volume from emerging markets countries has until now been increasing. 
to imagine a world in which we understand political risk as well as we understand most of the other risks investors face. O ne scholar, reflecting generally on the treatment of uncertainty in economics, said:

A key word... is uncertainty-genuine, residual uncertainty - not knowing with any substantial confidence many aspects of what (or how much of what) the future holds. R eal world economic actors, peering ahead in time as they must, do not love uncertainty. B ut, on the whole, they accept it rationally as a fact of life, and, over time, have invented institutions and precautionary tactics of remarkable ingenuity to shrink it down considerably and otherwise mitigate its negative effects.

For many economists, by contrast, uncertainty is the ultimate $\mathrm{H}$ allowe'en scare word. Throw it into a theoretical discussion ... and horrid visions are conjured of a nihilistic economics suddenly stripped of all pretensions to science and reduced to unstructured, pseudosociological chit-chat. A fter the manner of mid-V ictorians confronted with sex, immediate attempts are instituted to cover up or transmute the unwanted intruder - to reduce it to safe, mathematically tractable probability distributions, to treat is as a series of shocks wholly exogenous to the economic system as modeled, or to argue that if people simply do the best they can with the information they do have, the essence of the model remains unscathed.

This is highly irrational. No good can come from treating in such dodgy fashion what real-world actors, all but unanimously, declare to be one of their central economic anxieties. Is not the admission of ignorance the beginning of wisdom. . .? To be sure, uncertainty, like atomic particles, is not directly observable.... But what people do about uncertainty. . . is eminently accessible to measurement and analysis. ${ }^{104}$

We should not be surprised at uncertainty in the rarefied world of finance. We also should not be surprised that dealing with uncertainty may require some adaptation to the standard models to reflect a complex event which defies ready, formulaic classification, and the limitations of our knowledge more generally. Indeed, adapting such a methodology to take into account unique, complex and dynamic events seems eminently rational, both inside and outside the realm of finance.

104. David M CQ ueen, On rereading Samuelson I: A teacher's perspective, CHALLENGE, Mar./A pr. 1994, at 43-44. 